\title{
Proposal of methodology for spatial analysis applied to human development index in water basins
}

\author{
Jomil Costa Abreu Sales • Darllan Collins da Cunha e Silva • Omar Yazbek Bitar • \\ Roberto Wagner Lourenço
}

Published online: 6 June 2018

(C) Springer Nature B.V. 2018

\begin{abstract}
Historically, the Human Development Index (HDI) is used to measure the socioeconomic performance of a population. Despite harsh criticism about its efficiency as an indicator of development, it is still widely used as a tool for public management planning. This study proposes a methodology using geoprocessing techniques to perform the mapping and prediction of HDI spatial distribution in the Una River Basin $\left(\mathrm{HDI}_{\mathrm{URB}}\right)$. We used data from the 2010 Demographic Census to calculate the sub-indexes of population longevity, education and income. After obtaining the results, we applied Ordinary Kriging geostatistical interpolation to obtain the continuous variation of HDI values. According to the results, the
\end{abstract}

J. C. A. Sales $(\bowtie) \cdot R$. W. Lourenço

Department of Environmental Engineering, São Paulo State University - UNESP, 3 de Março Avenue, no 511, PO Box 18087-180, Sorocaba, São Paulo State, Brazil e-mail: jomilc@gmail.com

R. W. Lourenço

e-mail: robertow@sorocaba.unesp.br

D. C. da Cunhae Silva

Sorocaba University - UNISO, Raposo Tavares, km, 92.5

Road, PO Box 18023-000, Sorocaba, São Paulo State,

Brazil

e-mail: darllanamb@yahoo.com.br

O. Y. Bitar

Institute for Technological Research - IPT, 31 - Av. Prof.

Almeida Prado, 532, PO Box 05508-901, Butantã,

São Paulo State, Brazil

e-mail: omar@ipt.br highest value of $\mathrm{HDI}_{\mathrm{URB}}$ was obtained in the northern region of the basin located near the urban area of the municipality of Ibiúna (0.86), decreasing as it approached the southern region (0.69), classified as an average human development. Finally, the methodology, despite some limitations, proved to be satisfactory, since it was able to represent internal differences in a water basin from the point of view of quality of life of the population. It may be applied as a tool for management and public administration.

Keywords Socioeconomic index · Geoprocessing · Kriging · Demographic Census

\section{Introduction}

The Human Development Index (HDI) is used for measuring quality of life across the world, since 1990, when the United Nations Development Program (UNDP) issued a first Human Development Report (HDR), which has been published on a regular basis every year. Seeing that, the UNDP has influenced the development debate worldwide for more than a quarter of a century by placing the richness of human life above the richness of the economy (UNDP 2018).

The HDI was established to place emphasis on individuals, more precisely on their opportunities to have a satisfying live, evaluating a potential for a 
population to have a long and healthy life, with access to knowledge and a certain financial life standard.

However, there are some limitations related to its applications. One of them is the index, which does not specifically reflect quality of life factors, such as empowerment movements or overall feelings of security, including inequality issues such as gender disparity or racial inequality, and other. There are additional indexes able to complement HDI to provide this answers (UNDP 2015).

Furthermore, another limitation of composite index, is that some indicator which mold the index, doesn't reflect the real situation evaluated (Kovacevic 2011). However, according to Abreu et al. (2011) and Haddad (2013) an important counterpoint is that HDI can be calculated at different population scales bringing more precision on the data.

Thus, this paper aims to address this counterpoint, calculating HDI in watershed scales, by using census tract as geographic unity, allied to Geographic Information System (GIS) to predict HDI spatial distribution and use it as a policy tool to guide efforts to drive the well-being of populations.

\section{Literature review}

Performance indicators are often used by countries, states and municipalities to quantify their development. The performance of such indicators is capable of provide information on the ecological and social dimensions of human communities and the sustainability of their activities. Such metrics allow facilitating the management of public policies, whose objective is to measure progress in each sector of society (Costanza et al. 2009; Kubiszewski et al. 2013; Lourenço et al. 2015; Silva et al. 2016a).

After the Great Depression and the World War II, the Gross Domestic Product (GDP) gained popularity as a performance indicator used by governments. Although it is a measurement of economic activity, which assigns monetary value to all goods produced in the country, it is commonly used to compare economic or social welfare at national and state levels. However, it was never conceived for this purpose. Therefore, it worked very poorly as a tool, since it is known that the economic growth of a society is not translated into well-being or quality of life (Costanza et al. 2004; Wesselink et al. 2007).
Contrary to popular belief, economic growth often reinforces social inequalities. Thus, by placing people at the center of a welfare analysis, the human development approach redefines the way we think and deal with international, national and local development (PNUD 2013).

An alternative to failures in social welfare measurements was the Human Development Index (HDI), developed by the United Nations Program in the 1990s, as a counterpoint to GDP per capita, used to measure the development of a given region. Since GDP is only concerned with the economic dimension, HDI is an indicator that aggregates GDP per capita, life expectancy at birth and adult literacy rate, that is, it meets the three most important requirements for the expansion of people's freedoms: opportunity to have a long and healthy life, access to knowledge and decent living standard, regarded as the major ingredients of development and progress (Van den Bergh 2009; Kubiszewski et al. 2013; PNUD 2013).

Although very simple, the HDI is a geometric mean of three ingredients, opportunity to have a long and healthy life, access to knowledge and decent living standard, resulting into a relevant amount of information. However, it remains one of the few indexes that are regularly compiled and widely disseminated by international organizations to allow systematic crosscountry comparisons (Alkire and Santos 2014, UNDP 2016).

This index was created to emphasize that people should be the main criteria for assessing the development of a country, instead of economic growth. The HDI can also be used to question national policy choices, asking how two countries with the same level of GDP per capita can end up with different human development outcomes (UNDP 2016).

As a composite index, HDI has some strengths and weaknesses, an example is that although the use of multiple indicators allows the researcher to observe an object of interest from multiple angles, it does not allow a detailed understanding of the phenomenon under consideration. Indeed, there are other pros and cons arguments related to HDI been used for a long time, alone or with other complements (Kovacevic 2011; UNDP 2016).

Another counterpoint of the HDI is that can be calculated at different population scales: countries, states, municipalities, districts, neighborhoods, and even census tracts, giving more accuracy at the data 
according to the scale (Abreu et al. 2011; Haddad 2013). Census tract is defined as the smallest territorial unit with identifiable physical limits in field and a size suitable for research activities. To consider the regional dynamics of an urban or rural area, the census tract is the most adequate scale. Then, the data of households and people used for drawing a picture of an entire demographic census are grouped by census tracts (Abreu et al. 2011; IBGE 2010).

From a set of demographic census data covering population, economy, literacy, among others, it is possible to calculate the HDI by census tract, establishing it as the smallest unit of analysis to represent the dynamics of local human development (Constantino et al. 2016).

In order to carry out an HDI distribution within a given area from census data, a scientific instrument capable of evaluating population statistics is used via spatial analysis. The Geographic Information System (GIS) allows quantitative geographic analyses of the dynamics of variables (Abreu et al. 2011).

Spatial analysis is the area of knowledge that aims to treat geographic data using mathematical and computational techniques. It operates on a set of georeferenced data to aid in the interpretation of the dynamics of certain physical, biological and population phenomena, providing support for decision-making (Câmara et al. 2004).

Several studies containing socioeconomic analyses have disseminated the techniques and methods of spatial analysis, thus becoming important references to the application of geostatistics (Lourenço et al. 2014; Constantino et al. 2016).

Nowadays, studies that use HDI to track the performance of cities, states and countries, are unable to proceed with the same methodology to study different areas in different scales, once this index was developed to analyses political division.

This study proposes a methodology using geoprocessing techniques to perform the mapping and prediction of HDI spatial distribution, capable to be applied in different scales, using as study area a watershed. It helps to understand the spatial distribution of census data and the continuous variation of the HDI of the Una River Basin (HDIURB) located in the municipality of Ibiúna, São Paulo state.

\section{Study area}

The Una River Basin (URB) is located in the municipality of Ibiúna, in the metropolitan region of São Paulo city, approximately $75 \mathrm{~km}$ from the capital. The Una River together with the Sorocabuçu River and the Sorocamirim form the Sorocaba River, one of the main tributaries of the left riverbank of the Tietê river, one of the main rivers of the São Paulo state making this basin an important study area for its relative size and population growth rate (Fig. 1).

According to the last census conducted in 2010, the municipality has 71,217 inhabitants. Its population density is 67.31 inhabitants per square kilometer, the average infant mortality rate is 16.57 per 1000 live births. In 2014, it had a GDP per capita of R\$ 18,966.35. The HDI of Ibiúna in 2010 was calculated as 0.710 , considered high according to the parameters of the Human Development Atlas of Brazil (IBGE 2017; PNUD 2013). Ibiúna has 129 census sectors. The URB is composed of 43 sectors in rural and urban areas (IBGE 2010).

\section{Methodology}

Obtaining data

We elaborated a digital cartographic database containing relevant information on the boundaries of the study area, its hydrographic network, contour lines and elevation points, and other relevant information that helped a cartographic recognition of the area. The census vectors were obtained from the IBGE's cartographic database, digital territorial meshes of 2010 (IBGE 2017).

To calculate the population of the basin, it was necessary to apply the weighted sum of the total population of the river basin divided by the area of census tracts, since some sectors are not fully included in the geographical delimitation of the basin.

The software ArcGis 10.1 and AutoCad Map 3D were used for scanning, vectorization and analysis of data and topographic charts.

We used the base report of the 2010 demographic census as data source, a result of the universe by census tract. The census universe is performed in all home units, and contains basic information of households and residents. However, sample census 

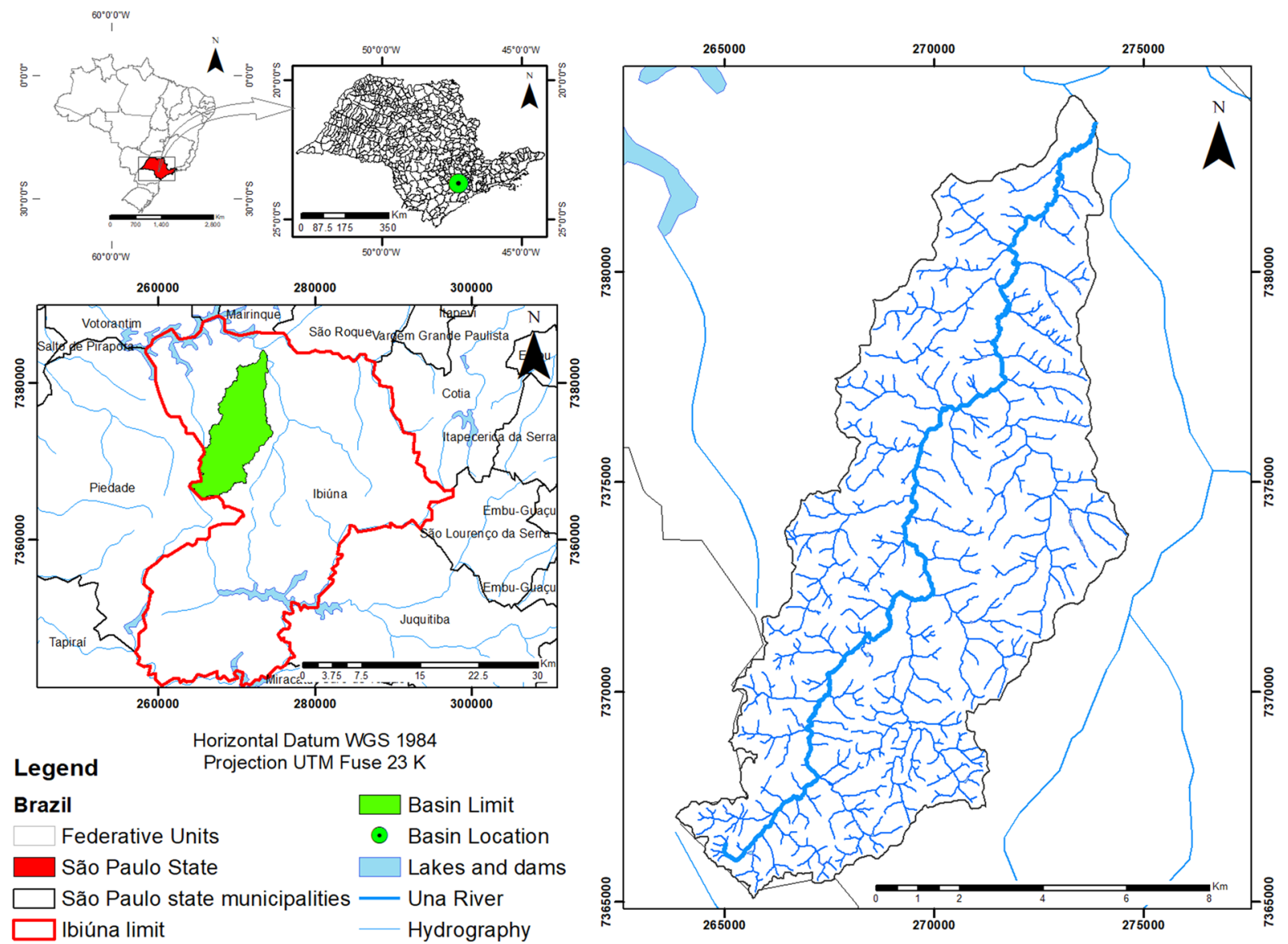

Fig. 1 Study area

variables, despite being more complete, are not sufficient for such an analysis because the size of the Ibiúna population and the URB population would not have sample representativity, since, in this sampling, only one per every ten households is counted (Abreu et al. 2011; IBGE 2010).

The HDI was created to measure the human development of countries, assessing income, education and longevity. Based on its importance and acceptance in society as an indicator of quality of life, it was applied to the municipal reality (Lima 2016).

Thus, we applied the calculation methodology of Municipal HDI, adapted from the Global HDI in 2012 by the PNUD Brazil, IPEA and João Pinheiro Foundation. It adjusted the methodology to the Brazilian context, seeking more adequate indicators at a municipal level (PNUD 2013).
Education dimension

It is composed of indicators of education level of the adult population and school flow of the young population. School flow is measured by the arithmetic mean of the percentage of children between 5 and 6 years attending school; the percentage of young people between 11 and 13 years attending the final years of regular primary education; the percentage of young people between 15 and 17 years with complete primary education; finally, the percentage of young people between 18 and 20 years with full education. Adult education is measured by the percentage of the population aged 18 years or over with complete elementary school (PNUD 2013).

Therefore, the URB Education HDI was calculated as the geometric mean between both indexes, with a weight of 1 for the educational index and a weight of 2 for the school flow index (Eq. 1). 
$H D I E_{U R B}=\sqrt[3]{E_{A} \times F_{E} \times F_{E}}$

where $\mathrm{HDIE}_{\mathrm{URB}}=$ Human Development Index of Education of the Una River Basin; $\mathrm{E}_{\mathrm{A}}=$ Adult education level index; $F_{E}=$ School flow index of the young population.

The variables used comprised information on the age of the population and people who were literate by age. It was obtained from the spreadsheets of the 2010 census databases (IBGE 2010).

Income dimension

It is composed of the income per capita of the population. Income per capita measures the average purchasing power of goods and services (Pinto et al. 2013). Thus, we used the same criterion as for census tracts. Total nominal income divided by total population residing in households in each sector resulted in the sectorized income per capita (IBGE 2010).

According to the Atlas of Human Development in Brazil, according to the methodology of HDI Municipal developed by the United Nations Development Program (PNUD 2013), we assigned maximum and minimum reference values according to the dollar purchasing-power-parity (\$PPP) as used for the Global HDI.

Therefore, the maximum and minimum limits converted to monthly income per capita are $\mathrm{R} \$$ 4033.00 and $\mathrm{R} \$ 8.00$, respectively. The minimum corresponds to the minimum as adopted by the Global HDI for countries. The maximum corresponds to average income of the tenth richest part of the population in the richest municipality of the country.

The calculation of HDI Income of the Una water basin by census tracts, adapted from the Global HDI, is calculated according to Eq. 2.

$H D I I_{U R B}=\frac{\left(\log _{p c i}-\log _{m r l}\right)}{\left(\log _{m a r l}-\log _{m r l}\right)}$

where $\mathrm{HDII}_{\mathrm{URB}}=$ Human Development Index of Income of the Una River Basin; $\log _{\mathrm{pci}}=$ Logarithm of income per capita of the census tract; $\log _{\mathrm{mrl}}$ $=$ Minimum reference logarithm; $\log _{\operatorname{marl}}=$ Maximum reference logarithm.

For this calculation, we used the variables referring to the total monthly nominal income of permanent private households and the total monthly nominal income of improvised private households, in addition to the total number of residents by census tracts.

Longevity dimension

According to the adaptation of the National HDI to the Municipal level, carried out by the United Nations Development Program-Brazil (PNUD 2004), the longevity dimension is calculated based on data on life expectancy at birth and mortality rates.

However, such information is provided only by the sampling census, making the usage of the same methodology impossible in this study because of absence of data by census tract. To solve this problem, we use the methodology adapted by Abreu et al. (2011), by which it is assumed that the longevity dimension of the HDIL $_{U R B}$ is the average of the indicator in all census tracts. Thus, we sought to find the population life expectancy of the Una River Basin by applying the value 0.832 , which corresponds to the HDI-Longevity of the Municipality of Ibiúna in 2010, inversely from the Eq. 3, which defines the HDIL in function of life expectancy (PNUD 2013):

$H D I L_{U R B}=\frac{(L E-25)}{(85-25)}$

where HDIL $_{\mathrm{URB}}=$ Human Development Index of Longevity of the Una River Basin; LE = Life expectancy in years; 25 and $85=$ Reference values, in years, corresponding to the minimum and maximum ages considered by the PNUD, respectively.

After obtaining the life expectancy of the municipality of Ibiúna in 2010, it was possible to determine the percentage of the number of people below minimal life expectancy by tract.

To transform this value, a cumulative distribution of people by age was performed for each census tract. Therefore, it was possible to identify the entire number of residents determined by age group.

In this way, we determined an integer value equivalent to the number of people immediately below the real value corresponding to the percentage of people below the life expectancy range of the total population for each census tract. Based on the number of people below the age assumed as the life expectancy and the cumulative distribution of people by age, we determined the age corresponding to the life expectancy of each sector. 


\section{Calculation of HDI spatialization}

After obtaining income, education and longevity subindexes, it was possible to calculate the HDI of the URB itself. The calculation was based on an adaptation of the Municipal HDI presented by the PNUD (2013), which is the cubic root of the multiplication of the three HDIs, according to Eq. 4:

$H D I_{U R B}=\sqrt[3]{\left(H D I E_{U R B} \times H D I I_{U R B} \times H D I L_{U R B}\right)}$

where $\mathrm{HDI}_{\mathrm{URB}}=$ Human Development Index of the Una River Basin; HDIE $_{\text {URB }}=$ HDI Education SubIndex of the Una River Basin; $\mathrm{HDII}_{\mathrm{URB}}=\mathrm{HDI}$ Income Sub-Index of the Una River Basin; HDIL URB- $_{\text {- }}$ $=$ HDI Longevity Sub-Index of the Una River Basin.

The HDIURB is a number that varies between 0 and 1. The closer to 1 , the greater the human development of a census tract, classified according to Table 1 and the Human Development Atlas of Brazil (PNUD 2013).

Spatial analysis of data

We used Ordinary Kriging as a linear estimation technique for the variables. The methodology weighs the measured values surrounding sampling units to derive a forecast in an unmeasured location. The general interpolation formula is a weighted sum of data, according to Eq. 5 (Boshi et al. 2012; Farmer 2016).

$Z\left(x_{0}\right)=\sum_{i=1}^{N} \lambda_{i} Z\left(x_{i}\right)$

where $x_{0}$ is the desired point, in $Z\left(x_{i}\right), i=$ $1,2, \ldots, N, x_{i}$ are the points measured, and $\Sigma \lambda_{i}$ is the sum of the weights assigned to them.

Table 1 Human development of the una river basin

\begin{tabular}{ll}
\hline Classification & HDI Intervals of Census tract \\
\hline Very low & $0.000-0.499$ \\
Low & $0.500-0.599$ \\
Medium & $0.600-0.699$ \\
High & $0.700-0.799$ \\
Very high & $0.800-1.000$ \\
\hline
\end{tabular}

According to Camargo (1997), by minimizing the error variance under the condition $\Sigma \lambda_{i}=1$, the weights are obtained from a system of Ordinary Kriging equations and may be written using matrix notation as described in Eq. 6:

$K \times \lambda=k \quad$ or $\quad \lambda=K^{-1} \times k$

where $K$ is the covariance matrix between the samples; $k$ is the covariance matrix between the samples and the point to be estimated; $\lambda$ is the vector of weights.

The covariates are obtained in function of distances between sampling points and the point to be estimated based on experimental semivariogram modeling. The function of the semivariogram theoretical model varies according to the model itself, and is presented in Eq. 7:

$\gamma(h)=f\left(C_{0}, C_{1}, a, h\right)$

where $\mathrm{C}_{0}=$ Nugget effect; $\mathrm{C}_{1}=$ Contribution; $a=$ Range; $h=$ Distance vector between two points.

The equation of the chosen theoretical model in each sample or non-sample pair was applied. The distance between them is the independent variable, thus obtaining the semivariance between the pair.

To represent the variability and the spatial continuity of HDI on the surface of the URB, the data referring to HDI sub-indexes, represented by the central point of the respective polygons of each census tract, called centroids, were considered as sample data.

The conversion of polygon values into points was performed automatically using the software ArcGis 10.1. To analyze the spatial continuity of the indicator, the first step was to model HDI semivariograms. After semivariance values were plotted in the semivariogram, we verified the presence of anisotropy on the semivariogram surface.

Using the software ArcGis 10.1, it was possible to adjust the experimental semivariograms. The fundamental parameters of the semivariogram, such as plateau, nugget effect and range, remained the same as those pre-established by the algorithm. However, some adjustments to lag numbers and bandwidth widths have been made. These parameters indicate the tolerance range used in exploratory variography (Abreu et al. 2011).

According to ESRI (2011), the lag size selection exerts important effects on the semivariogram. For example, if the lag size is too great, short-range 
autocorrelation may be masked. After several tests, we found that the best type of experimental semivariogram for each indicator was the Gaussian.

\section{Results and discussion}

The study of population dynamics of the URB is of great interest since it is one of the most important sources of supplies to the Itupararanga Hydropower Plant, the main water reservoir in the region. It supplies an estimated population of more than 1.5 million people, in addition to containing extensive strips of native forests and being an area of economic interest due to agricultural expansion (IPT 2008; Silva et al. 2016b).

According to the Brazilian Human Development Atlas (PNUD 2013), based on the information of the last Brazilian demographic census in 2010 (IBGE 2010), the state of São Paulo, including the municipality of Ibiúna, had an increasing development in the HDI. However, the municipality of Ibiúna has made a big leap since 1991, when it was classified as having a very low and low HDI in 2000, and a high HDI in 2010. Table 2 shows a comparison of HDI and its subindexes at national, state and municipal levels, and the HDI of the Una River Basin (URB) in 2010.

In the same way, a study in Mexico worked to adapt the index aiming to obtain distribution HDI measurement between the states and municipalities, presenting a new parametric class of human development indices that includes the original HDI as well as a family of distribution sensitive indices that satisfy all the basic properties for an index of human development. As a result, he had a reorganization of the HDI ranking of the states in México (Foster et al. 2007).

Abreu et al. (2011) in a similar study proposed a new method to calculate a HDI spatial analysis between cities in the state of Minas Gerais, in Brazil. This study allows to understand analysis of the spatial continuity of HDI intra-urban.

\section{HDI Income sub-index}

According to Abreu et al. (2011), the measurement of the economic aspect of the HDI calculated at a municipal level is made based on income per capita using data per census tract. The Una River Basin has a population of 19,000 inhabitants, with a territorial area of approximately $100 \mathrm{~km}^{2}$. The results presented per census tract of the Una water basin are represented by choropleth maps.

The value of the sub-index Income was 0.665 , classified as Average according to the range of values defined by the PNUD (2013). The income per capta of the Una basin in 2010 was R \$ 540.44. However, some census tracts present an income above this value. It is possible to observe in the map of Fig. 2 that income is concentrated in the northern region of the basin, where part of the urban center of the municipality of Ibiúna is located. The central portion and the southern region of the basin present lower values of income per capita, consequently with HDI income values of Average for the central part, Low for the southern part, and High for the northern region, as classified according to the classes defined by the PNUD (2013).

According to Lopes et al. (2016), the central region of the basin is predominantly composed of agricultural areas with a high potential for urban expansion, evidencing the distribution of values referring to the sub-index Income.

Two limitations on the application of this methodology should be mentioned. As reported by Abreu et al. (2011) in a similar study carried out in the municipality of Viçosa, Minas Gerais state, the first limitation is that the only variable indicative of monthly income is the one corresponding to people responsible for private permanent and private improvised households, which does not correspond to the total income of the tract, since it excludes other residents. The second limitation is that IBGE data include only the income of the heads of private and permanent households, excluding the income from heads of households residing in other types of households. However, the number of people residing in other types of households is low, not causing great distortions in the study results.

\section{HDI Longevity sub-index}

The longevity indicator reflects the health conditions of a region, measuring life expectancy of people at birth when mortality conditions are constant. Longevity may also be interpreted as an indicator of other aspects of well-being, such as adequate nutrition and 
Table 2 Comparison of the HDI sub-indexes Income, Longevity and Education, and HDI index

\begin{tabular}{lllll}
\hline Year & \multicolumn{2}{l}{2010} & & \\
\cline { 2 - 5 } Local & HDI Income & HD Longevity & HD Education & HDI \\
\hline Brazil & 0.739 & 0.816 & 0.637 & 0.727 \\
São Paulo & 0.789 & 0.845 & 0.719 & 0.783 \\
Ibiúna (SP) & 0.700 & 0.832 & 0.614 & 0.710 \\
URB & 0.665 & 0.810 & 0.810 & 0.760 \\
\hline
\end{tabular}

good health (Bergh and Nilsson 2010; Costanza et al. 2009).

The longevity dimension is calculated using data on life expectancy at birth, which in turn is based on mortality rates. However, this type of information is obtained only by sampling census, which prevents the use of the same methodology of this study, since this type of data is not available by census tract. To address this problem, we assumed that the longevity dimension of the URB is the mean of the indicator in all sectors (Abreu et al. 2011; PNUD 2013).

Given this premise, with the life expectancy value of the municipal HDI-Longevity of Ibiúna equal to 0.832 (Table 2), we obtained the life expectancy value of the URB (0.746), that is, the life expectancy at birth of the resident population in URB is 75 years.

By analyzing the cumulative distribution of people by age in the municipality based on the accumulated sum of the number of people at each age, we verified that $96.4 \%$ of the total population of the basin is within the age group between 0 and 75 years. With the previously admitted condition that municipal longevity is a sectorized average, $96.4 \%$ of the population of each sector are below its life expectancy age.

Thus, we obtained the result for the Longevity subindex per census tract, in addition to the URB HDI Longevity value, which was 0.810 , classified as Very High. However, the basin presented variations between census tracts classified as Average and Very High. The lowest values were attributed to two tracts to the north of the basin, and there was a third sector with a value lower than 0.700 , that is, an Average HDI Longevity. The central portion of the basin is classified as having a High HDI, and a census tract to the north, located near the urban center, and another in the southeast region of the basin were classified as Very High, with values of 0.91 and 0.93 , respectively, as shown by Fig. 3 .

\section{HDI Education sub-index}

HDI Education is a composition of indicators of education level of the adult population and the school flow of the young population. URB's HDI Education is classified as Very High (0.810).

According to the results, $68.18 \%$ of the adult population (18 years or older) of the URB, in 2010, have a complete elementary education, that is, the adult education level of the basin is 0.681 . Concerning indicators of school flow of the young population, $60.42 \%$ of children between 5 and 6 years of age were enrolled in schools, $97 \%$ of children aged between 11 and 13 years were in the final years of elementary education, $97.93 \%$ of children between 15 and 17 years completed the elementary education, and $97.72 \%$ of young people between 18 and 20 years completed high school. Therefore, the school flow rate of the young population was 0.882 .

According to PNUD (2013), the HDI Education is the geometric mean between the education level index of the adult population and the school flow of the young population, with a weight of 1 for the education index and a weight of 2 for the school flow index. Therefore, the HDI Education of the URB is 0.810 , as Table 2 shows.

The distribution of HDI Education among census tracts may be observed in the map of Fig. 4, where only two among the census tracts are classified as High. The others are classified with a Very High HDI Education. The sectors with the highest values are located near the urban area of Ibiúna.

\section{Una River Basin HDI}

The results for the URB HDI represent the ability of the population residing in all census tracts to have a long and healthy life, access to knowledge and a certain financial life standard. 
Fig. 2 Thematic map of the HDI Income sub-index

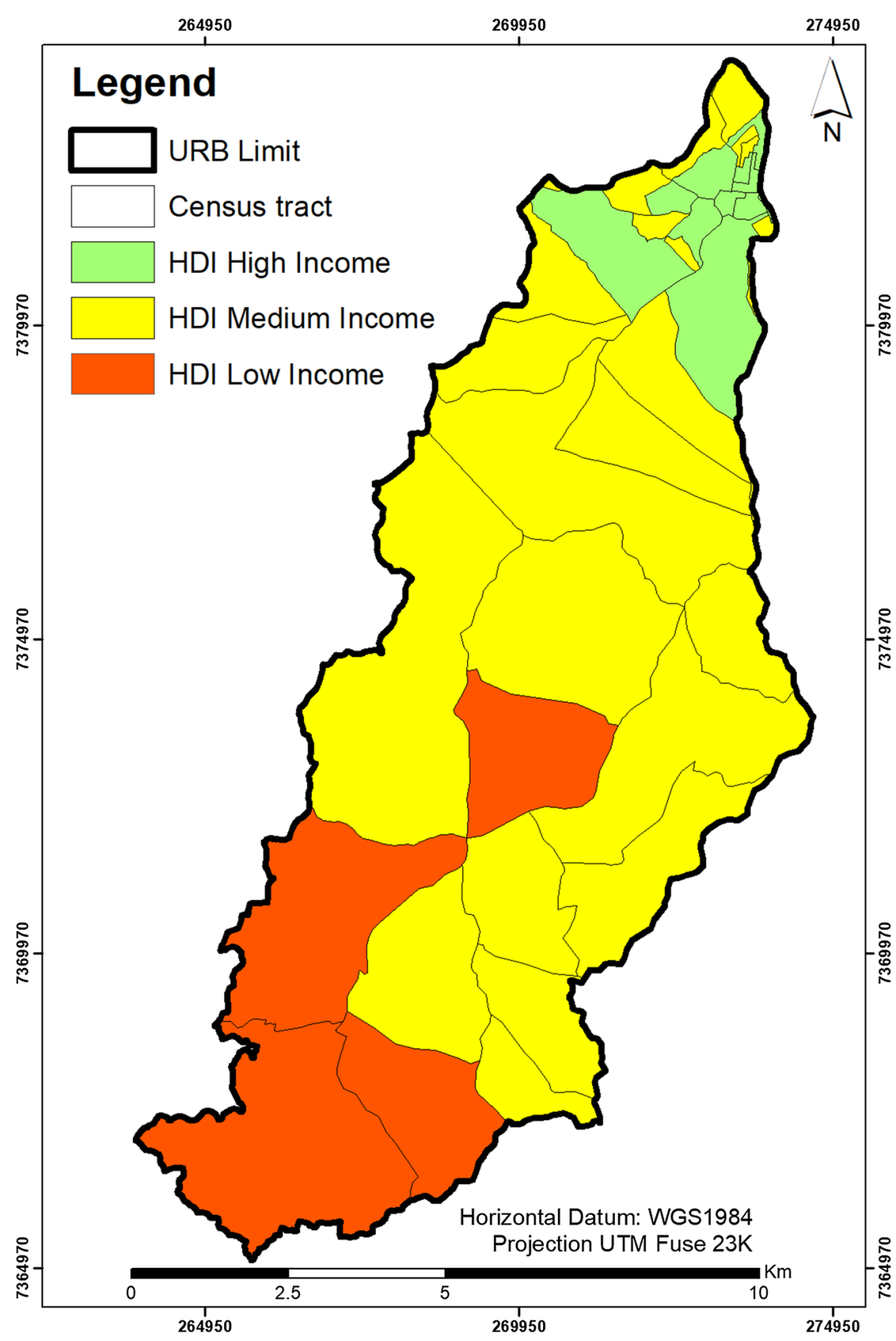

It is possible to observe in the map of Fig. 5 the spatial distribution of census tracts classified according to the terms adopted by the PNUD (2013). It is possible to observe that only one sector, located in the southern region of the basin, is classified as having an Average HDI (31 tracts), most sectors in the middle part of the basin had a High HDI, and finally, 11 tracts located in the northern region, close to urban areas, are classified as having a Very High HDI.

Figure 5 shows the spatial distribution of HDI classes of census tracts. It shows a concentration of the highest HDI values in the northeast region of the basin and average and low values distributed between the central and the southern regions. 
Fig. 3 Thematic map of the HDI Longevity sub-index

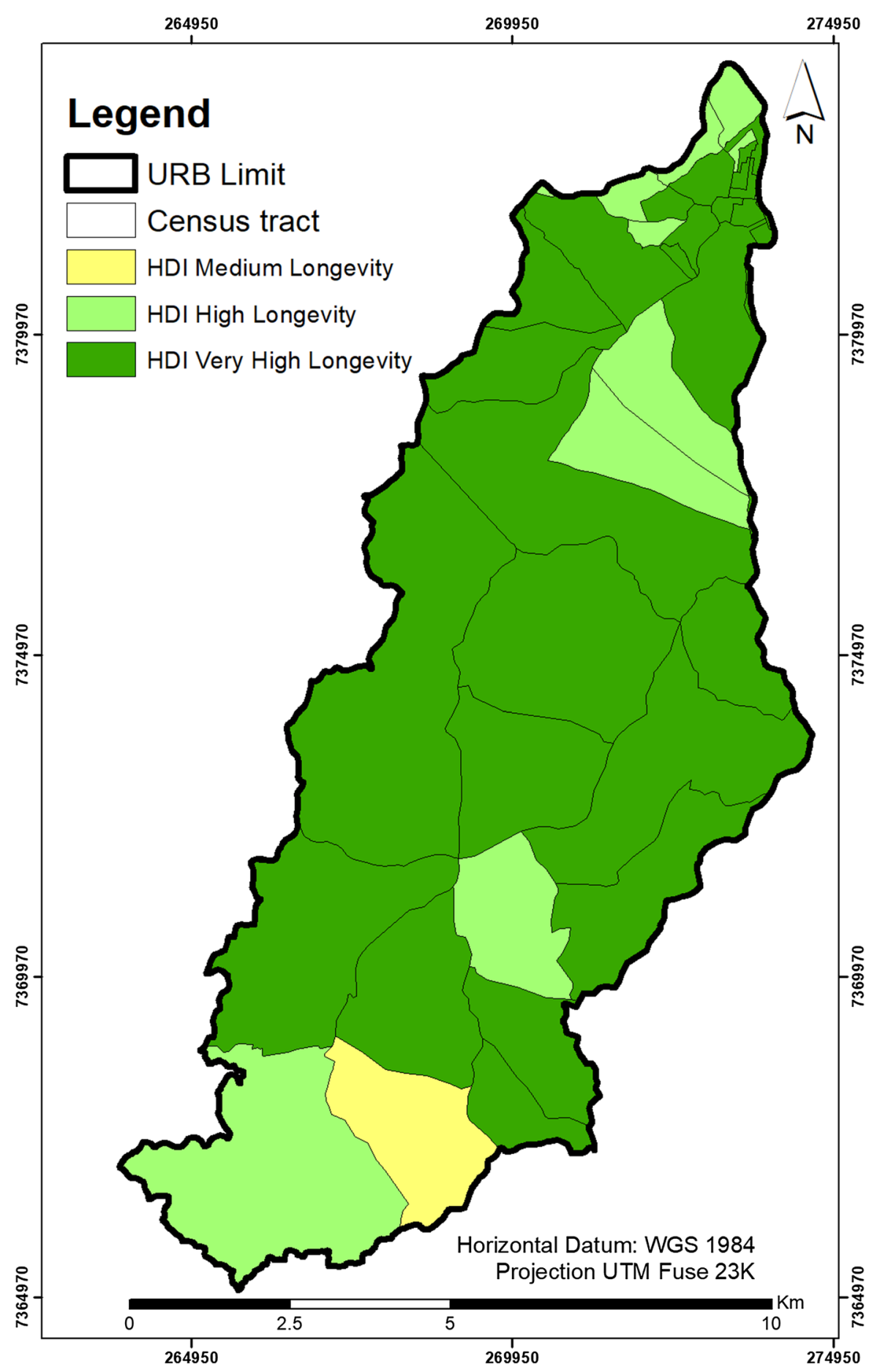

surface values (Gong et al. 2014). Kriging is a method of interpolation based on weights of sample data, distance between two samples and variance between them. It is also based on statistical models that include
Interpolation techniques in Geographical Information Systems (GIS) are powerful tools for predicting 
Fig. 4 Thematic map of the HDI Education sub-index

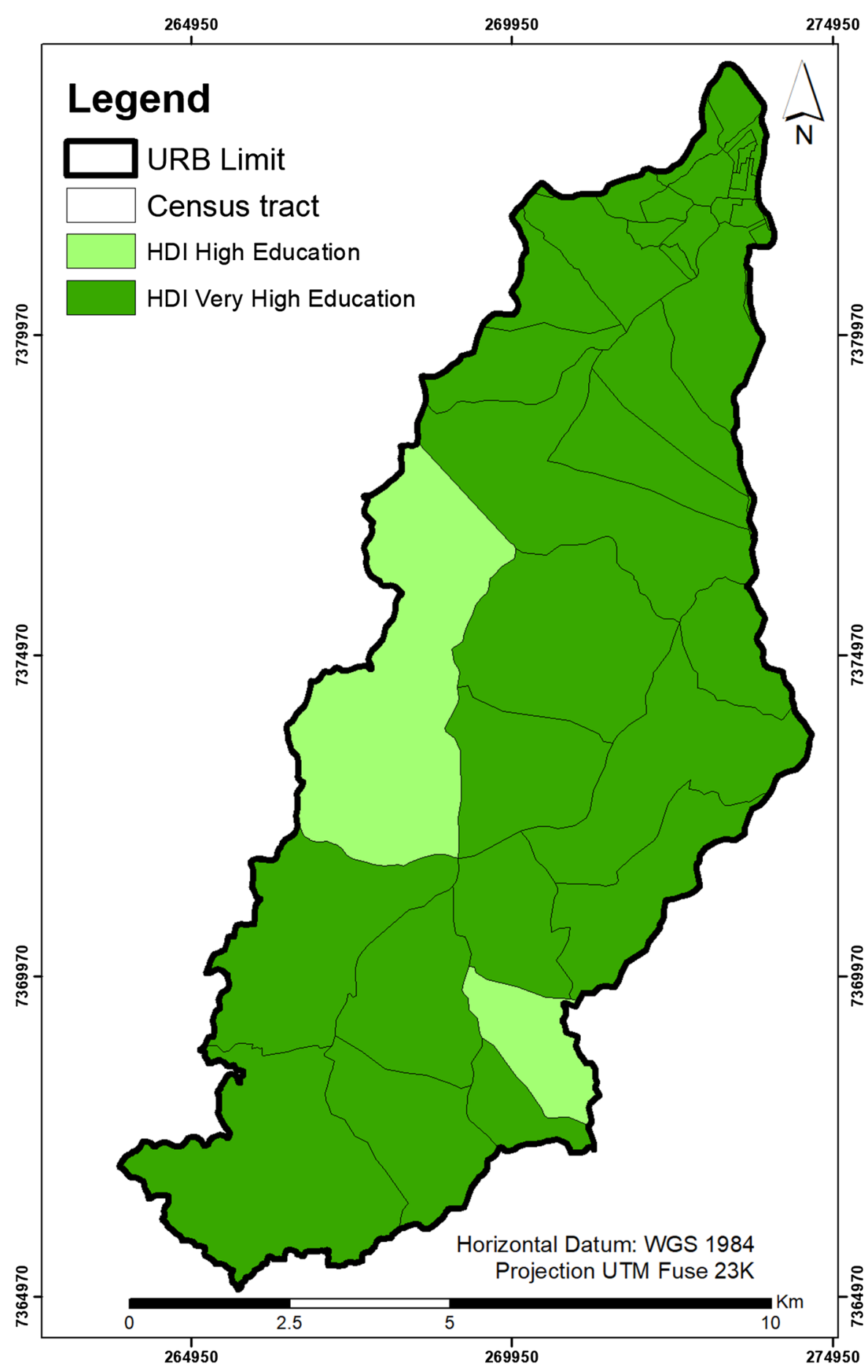

autocorrelation, that is, statistical relations between measured points. Because of this, geostatistical techniques not only have the ability to produce a surface forecast, but also provide some measurements of certainty or precision of predictions (Carson 2013; Cressie 2015).

Kriging extracts information from a semivariogram to obtain optimal weights to be associated with 
Fig. 5 Thematic map of human development index of the una river basin

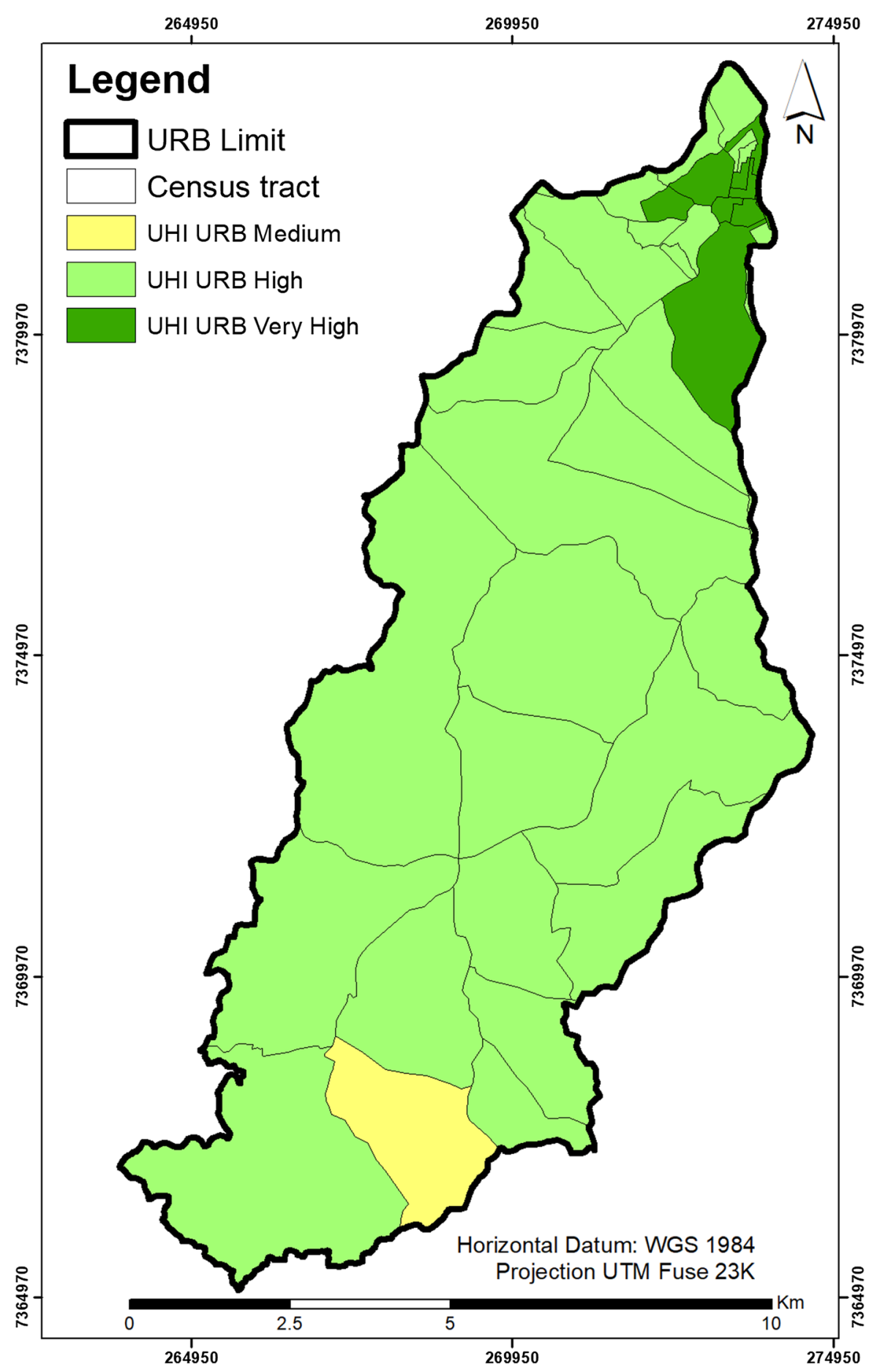

samples to estimate values at a given point. Ordinary Kriging is a linear estimation technique for a regionalized variable that meets the intrinsic hypothesis, and that does not require prior knowledge of means. It assumes the hypothesis of quasi-stationarity, also called local stationarity (Landim 2004; Cressie 2015).

According to ESRI (2011), Kriging is based on the theory of regional variables, assuming that the spatial 
variation in a phenomenon represented by z-values is statistically homogeneous throughout its surface. This hypothesis of homogeneity is fundamental to the theory of regional variables.

The interpolation was applied based on the values of sub-indexes attributed to the centroid of each census tract as sampled data. According to the method of Martin (1980), the process of constructing continuous population surfaces is performed based on zonal data. It is assumed that each individual inside a polygon has the inherent characteristics of such polygon. However, we emphasize that data are conditioned to the interferences by problems of modifiable area units. Thus, any surface constructed using zonal data will be influenced by such factors, and any analysis applied to them should take such factors into account.

The most applied procedure for the generation of population surfaces consists in assigning the value of the attribute associated to an area unit, where a constant density distribution is assumed throughout the interior of an area to an internal point of this area equal to the centroid (Martin 1980).

According to results obtained by interpolation, anisotropy may be observed in the spatial distribution of the $\mathrm{HDI}_{\mathrm{URB}}$. This is because of more developed regions than others, characterized by differences in the presence of infrastructure and concentration of urban services, with a different variation in different directions. After several tests, we found that the best type of experimental semivariogram for each indicator was the Gaussian.

The fundamental parameters of the semivariogram were a Nugget Effect $\left(\mathrm{C}_{\mathrm{o}}\right)$ of 0.0007466 and a

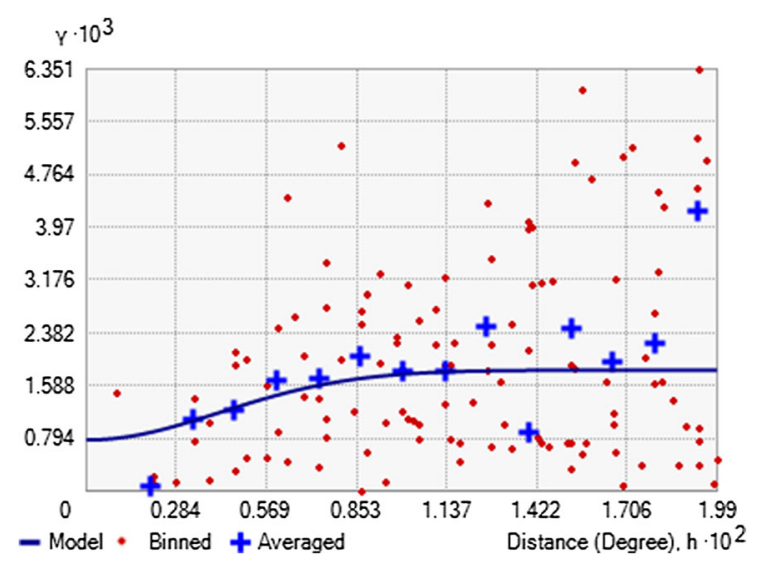

Fig. 6 Gaussian semivariogram
Table 3 Parameters of validation errors

\begin{tabular}{ll}
\hline Parameters of estimation errors & HDI \\
\hline Regression function & $0.379 \times 0.490$ \\
Average & 0.0005816 \\
RMS & 0.03680 \\
Standardized average & 0.009575 \\
RMS standardized & 0.8988 \\
\hline
\end{tabular}

Contribution (C) of 0.001053 , with an angular tolerance of $45^{\circ}$. Figure 6 shows the semivariogram.

The semivariogram shows the spatial autocorrelation between sampling points according to the Tobler's principle, which states that closer things are more similar than more distant things (Abreu et al. 2011; Tavares 2009).

The analyses of prediction errors show that the adjusted models were satisfactory. This is observed by the lines of the respective regression functions, which have intercepts always smaller than the unit. Crossevaluation uses all data to estimate tendency and autocorrelation models (ESRI 2011). The values presented as means of estimation errors, as well as mean square values (RMS), were also considered good.

According to Table 3, the results of mean prediction error represent an unbiased prediction since they are close to zero. However, according to standardized mean values, they are lower than the standardized RMS, underestimating the variability of forecasts.

Figure 7 shows the prediction map of HDI distribution in the river basin. The values are classified, according to the classes defined by the Human Development Atlas of Brazil (2013), between Average, High and Very High HDI.

It is possible to observe a high concentration of values in the northern region of the basin, where the urban center of Ibiúna is located, with a variation between $\mathrm{HDI}_{\mathrm{URB}}$ between 0.79 and 0.86 . The central and southern regions of the basin were classified with low values, varying between 0.71 and 0.78 . The region with the lowest $\mathrm{HDI}_{\mathrm{URB}}$ is the southern region, with values lower than 0.70 .

According to the analysis of the basin, the region classified with an HDI lower than 0.80 (Average) and a High HDIURB coincides with predominantly agricultural areas, especially in the central portion of the basin. The southern region, with an Average 
Fig. 7 Spatial continuity map of the Una River Basin HDI

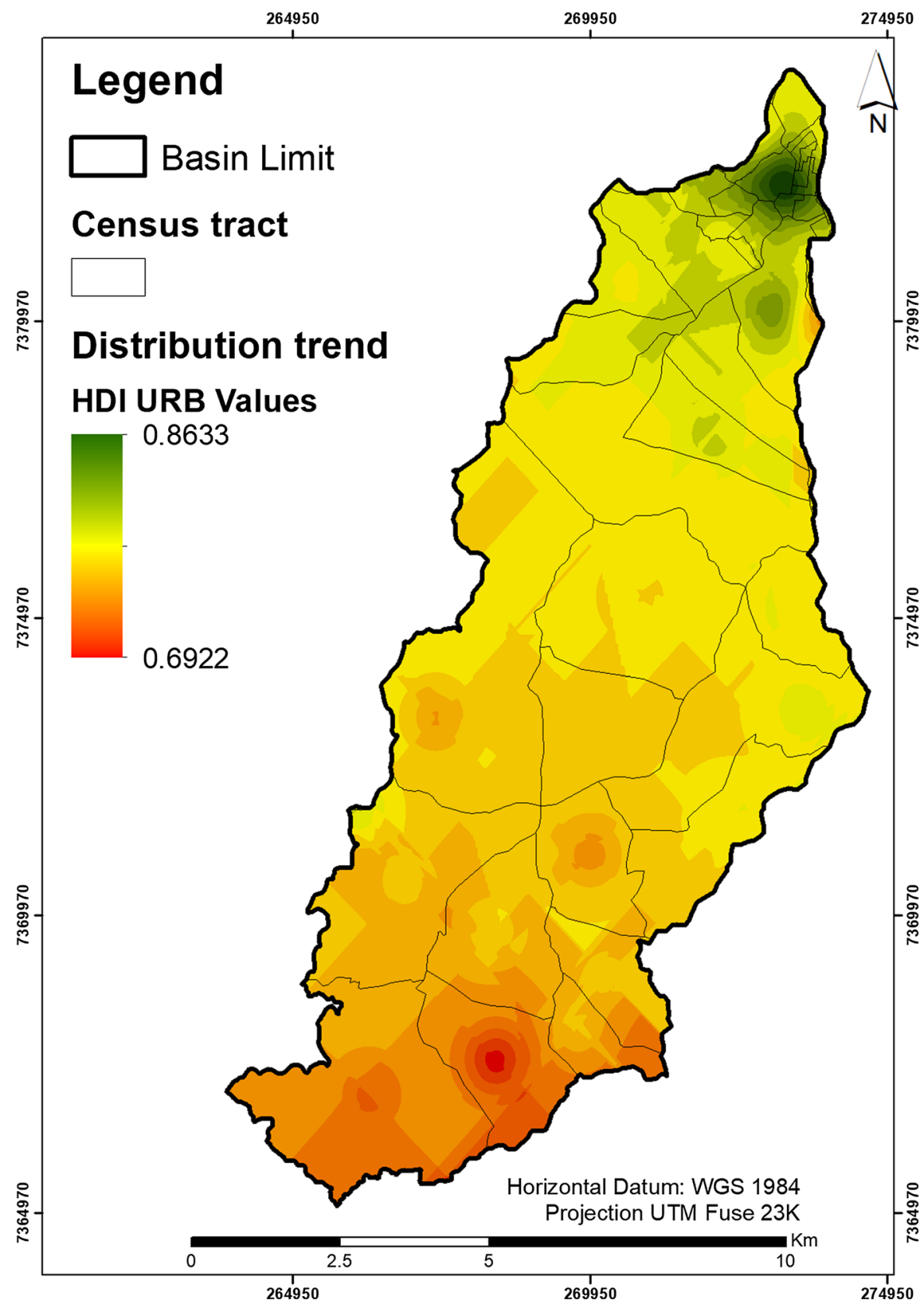

HDIURB, is composed of areas of native vegetation, pasture areas and few agriculture areas (Lopes et al. 2016).

Bahandari et al. (2015) shows in their study conducted in Nepal an association between demography and educational level and anthropic interferences, such as soil erosion. In this sense, the greater the number of families without adequate housing conditions and uneducated inhabitants, i.e., with low HDI values, the greater the tendency to cause environmental degradation in a higher proportion.

According to Silva et al. (2016a), who made an URB soil and vegetation cover mapping, low and average HDI regions are associated with short and long-term cropping areas, as well as dirty fields and exposed soil.

The analyses showed the importance of taking into account socioeconomic aspects combined with other 
variables. However, further studies are needed to confirm the occurrence of such relations in the Una River basin. Despite the criticism of its effectiveness, because it does not take into account issues such as sustainability or society well-being, the HDI remains a well-established indicator. It was chosen because of its importance, and it still is an index used as a comparative measure to classify countries, states and cities according to their degree of development.

\section{Conclusion}

We conclude by stressing the importance of understanding the socioeconomic dynamics of a given area, contributing to an effective reading of the reality of the local population and helping in decision-making as an area management tool.

The methodology used, despite some limitations, proved to be satisfactory, since it was able to represent internal differences of a water basin from the point of view of the quality of life of populations.

With respect to the generation of continuous surfaces, Kriging is as an ideal process of socioeconomic data interpolation, since it takes variability into account. Deterministic interpolators would consider variations between samples as constant. Therefore, a spatial analysis of socioeconomic indicators using this interpolation method allows the understanding of their behavior throughout the basin, since the boundaries of tracts are eliminated by using it.

This study focused on the application of a methodology for the calculation and the spatial analysis of the HDI of the Una River Basin. However, it can be applied at different scales, as well as to other river basins and municipalities. We suggest that such methodology be applied to more socioeconomic indicators, whether from census or not, as well as aggregated by area or point, or even taking into account environmental issues, using the variations of HDI as models of prediction and decision-making for public policies regarding social and environmental issues.

Acknowledgements To the Fundação de Apoio ao Instituto de Pesquisas Tecnológicas (FIPT) for the scholarship during the study. To the Instituto de Pesquisas Tecnológicas of São Paulo (IPT) for the participation of the first author in the New Talents Program.

\section{Compliance with ethical standards}

Conflict of interest The authors declare that they have no conflict of interest.

\section{References}

Abreu, M. V. S., Oliveira, J. C., Andrade, V. D. A., \& Meira, A. D. (2011). Proposta metodológica para o cálculo e análise espacial do IDH intraurbano de Viçosa-MG. Revista Brasileira de Estudos de População. https://doi.org/10. 1590/S0102-30982011000100009.

Alkire, S., \& Santos, M. A. (2014). Measuring acute poverty in the developing word: Robustness and scope of the multidimensional poverty index. Word Development. https:// doi.org/10.1016/j.worlddev.2014.01.026.

Bergh, A., \& Nilsson, T. (2010). Good for living? On the relationship between globalization and life expectancy. Word Development. https://doi.org/10.1016/j.worlddev.2010.02. 020 .

Bhandari, K. P., Aryal, J., \& Darnsawasdi, R. (2015). A geospatial approach to assessing soil erosion in a watershed by integrating socio-economic determinants and the RUSLE model. Natural Hazards. https://doi.org/10.1007/ s11069-014-1321-2.

Boshi, L. S., Galo, M. L. B. T., Rotta, L. H. S., \& Watanabe, F. S. Y. (2012). Mapeamento do Biovolume de Plantas Aquáticas Submersas a Partir de Dados Hidroacústicos e Imagem Multiespectral de Alta Resolução. Planta Daninha. https://doi.org/10.1590/S0100-83582012000300008.

Câmara, G., Vieira, M. A. M., Suzana, D., \& Sá, M. C. (2004) Análise Espacial e Geoprocessamento Gilberto. In Análise Espacial de Dados Geográficos, EMBRAPA, Brasília.

Camargo, E. C. G. (1997). Desenvolvimento, implementação e teste de procedimentos geoestatísticos (Krigagem) no sistema de processamento de informações georreferenciadas. São José dos Campos: INPE.

Carson, B. D. (2013). Testing kriging-based areal interpolation for census-based socioeconomic data. Redlands: University of Redlands.

Constantino, M., Pegorare, A. B., \& Costa, R. B. D. (2016). Performance of HDI and per capita GDP regional of municipalities of Mato Grosso do Sul, Brazil, between 2000 and 2010 Performance de HDI. Interações. http://dx. doi.org/10.20435/1984042X2016207.

Costanza, R., Erickson, J., Fligger, K., Adams, A., Adams, C., Altschuler, B., et al. (2004). Estimates of the Genuine Progress Indicator (GPI) for Vermont, Chittenden County and Burlington, from 1950 to 2000. Ecological Economics. https://doi.org/10.1016/j.ecolecon.2004.04.009.

Costanza, R., Hart, M., Posner, S., \& Talberth, J. (2009). Beyond GDP: The need for new measures of progress beyond GDP: The need for new measures of progress. Boston University press.

Cressie, N. (2015). Statistics for spatial data. Revised Edition. Wiley. Iowa State University Press.

ESRI (2011). ArcGIS Desktop. Release 10. Redlands Environmental Systems Research Institute. 
Farmer, W. H. (2016). Ordinary kriging as a tool to estimate historical daily streamflow records. Hydrology and Earth System Sciences. https://doi.org/10.5194/hess-20-27212016.

Foster, E. J., Lopes-Calva, L. F., \& Szekely, M. (2007). Measuring the distribution of human development: Methodology and an application to Mexico. Journal of Human Development. 1464988052000342220.

https://doi.org/10.1080/

Gong, G., Mattevada, S., \& O'bryant, S. E. (2014). Comparison of the accuracy of kriging and IDW interpolations in estimating groundwater arsenic concentrations in Texas. Environmental Research. https://doi.org/10.1016/j.envres. 2013.12.005.

Haddad, M. A. (2013). Examining the spatial distribution of urban indicators in São Paulo, Brazil: Do Spatial Effects Matter? In Sirgy J, Phillips R, \& Rahtz D (Eds) Community Quality-of-Life Indicators: Best Cases VI, Curitiba, Brazil.

IBGE. (2010). Base de informações do Censo Demográfico 2010: Resultados do Universo por setor censitário. IBGE. Rio de Janeiro.

IBGE-Instituto Brasileiro de Geografia e Estatística. (2017). Cidades @. http://www.cidades.ibge.gov.br/v4/brasil/sp/ ibiuna/panorama. Accessed 26-4-2017.

IPT Instituto de Pesquisas Tecnológicas. (2008). Relatório técnico $\mathrm{N}^{\mathrm{o}} 104.269-205$. Plano de Bacia da Unidade de Gerenciamento de Recursos Hídricos do Sorocaba e Médio Tietê (UGRHI 10)—Revisão Para Atendimento Da Deliberação CRH 62(1) FEHIDRO, São Paulo.

Kovacevic, M. (2011). Review of HDI critiques and potential improvements, Human development research paper. New York: UNDP.

Kubiszewski, I., Costanza, R., Franco, C., Lawn, P., Talberth, J., Jackson, T., et al. (2013). Beyond GDP: Measuring and achieving global genuine progress. Ecological Economics. https://doi.org/10.1016/j.ecolecon.2013.04.019.

Landim, P. M. B. (2004). Introdução à análise estatística de dados geológicos multivariados. São Paulo State: São Paulo State University Press.

Lima, R. F. P. D. E. (2016). Espacialização dos Índices de Desenvolvimento Humano-IDH por cartogramas corocromáticos estatísticos. Dissertation, Federal University of Santa Catarina.

Lopes, E. R. D. N., Souza, J. C., Sousa, J. A. P., AlbuquerqueFilho, J. L. \& Lourenço, R. W. (2016) Socioeconomic and environmental determinants on the urban potential of the Una Watershed, Ibiúna, SP. REDE: Revista Eletrônica do PRODEMA. https://doi.org/10.22411/rede2016.1002.01.

Lourenço, R. W., Silva, D. C. C., Martins, A. C. G., Sales, J. C. A., Roveda, S. R. M. M., \& Roveda, J. A. F. (2015). Use of fuzzy systems in the elaboration of an anthropic pressure indicator to evaluate the remaining forest fragments. Environmental Earth Sciences. https://doi.org/10.1007/ s12665-015-4253-6.

Lourenço, R. W., Silva, D. C. C., \& Sales, J. C. A. (2014). Development of a methodology for evaluation of the remaining forest fragments as a management tool and environmental planning. Ambiência. https://doi.org/10. 5935/ambiencia.2014.03.03.
Martin, D. (1980). Mapping population data from zone centroid locations. Transactions of the Institute of British Geographers, 14, 90-97.

Pinto, R., Jonge, V. N., Neto, J. M., Domingos, T., Marques, J. C., \& Patrício, J. (2013). Towards a DPSIR driven integration of ecological value, water uses and ecosystem services for estuarine systems. Ocean and Coastal Management. https://doi.org/10.1016/j.ocecoaman.2011.06. 016.

PNUD (2004). Relatório do Desenvolvimento Humano 2004: Liberdade Cultural num Mundo Diversificado PNUD. Relatório do Desenvolvimento Humano 2004: Liberdade Cultural num Mundo Diversificado. New York. Accessed on April 21, 2017 www.pnud.org.br.

PNUD (2013). Atlas do Desenvolvimento Humano no Brasil 2013 PNUD. Brasília. Accessed on Nov 15, 2016 http:// atlasbrasil.org.br/2013/pt/perfil/rio-de-janeiro_rj.

Silva, D. C. C., Albuquerque-Filho, J. L., Sales, J. C. A. S., \& Lourenço, R. W. (2016a). Uso de indicadores morfométricos como ferramentas para avaliação de bacias hidrográficas. Revista Brasileira de Geografia Física, 9, 627-642.

Silva, D. C. C., Sales, J. C. A. S., Albuquerque-Filho, J. L., \& Lourenço, R. W. (2016b). Características morfométricas e suas implicações no acúmulo de sedimentos em reservatórios. O caso da represa Hedberg, Iperó/SP. Ra'e Ga, $36,225-245$.

Tavares, J. M. (2009). O Que Acontece Com O Município Vizinho Interessa? Um Estudo De Econometria Espacial Aplicado a Santa Catarina (1998-2002). Textos de Economia. https://doi.org/10.5007/2175-8085. 2009v12n1p38.

UNDP-United Nations Development Programme (2015). Training Material for Producing National Human Development Reports. Human Development Report. Office Occasional paper. New York: United Nations Development Programme. Accessed on June 29, 2018 http://hdr. undp.org/sites/default/files/hdi_training.pdf.

UNDP-United Nations Development Programme (2016). National Human Development Report. United Nations Development Programme: Accessed on Dec 12, 2017 http://hdr.undp.org/en/content/human-developmentindex-hdi.

UNDP-United Nations Development Programme (2018). National Human Development Report 2018. Planning the Opportunities for a Youthful Population. New York. United Nations Development Programme. Accessed on June 29, $2018 \mathrm{http} / / / \mathrm{hdr}$.undp.org/sites/default/files/reports/ 2843/978-92-1-126436-4_web.pdf.

Van Den Bergh, J. C. J. M. (2009). The GDP paradox. Journal of Economic Psychology. https://doi.org/10.1016/j.joep. 2008.12.001.

Wesselink, B., Bakkes, J., Best, A., Hinterberger, F., \& Brink, P. (2007). Measurement beyond GDP: Background paper for the conference beyond GDP: Measuring progress, true wealth, and the well-being of nations. International Conference Brussels. https://doi.org/10.2779/54600. 